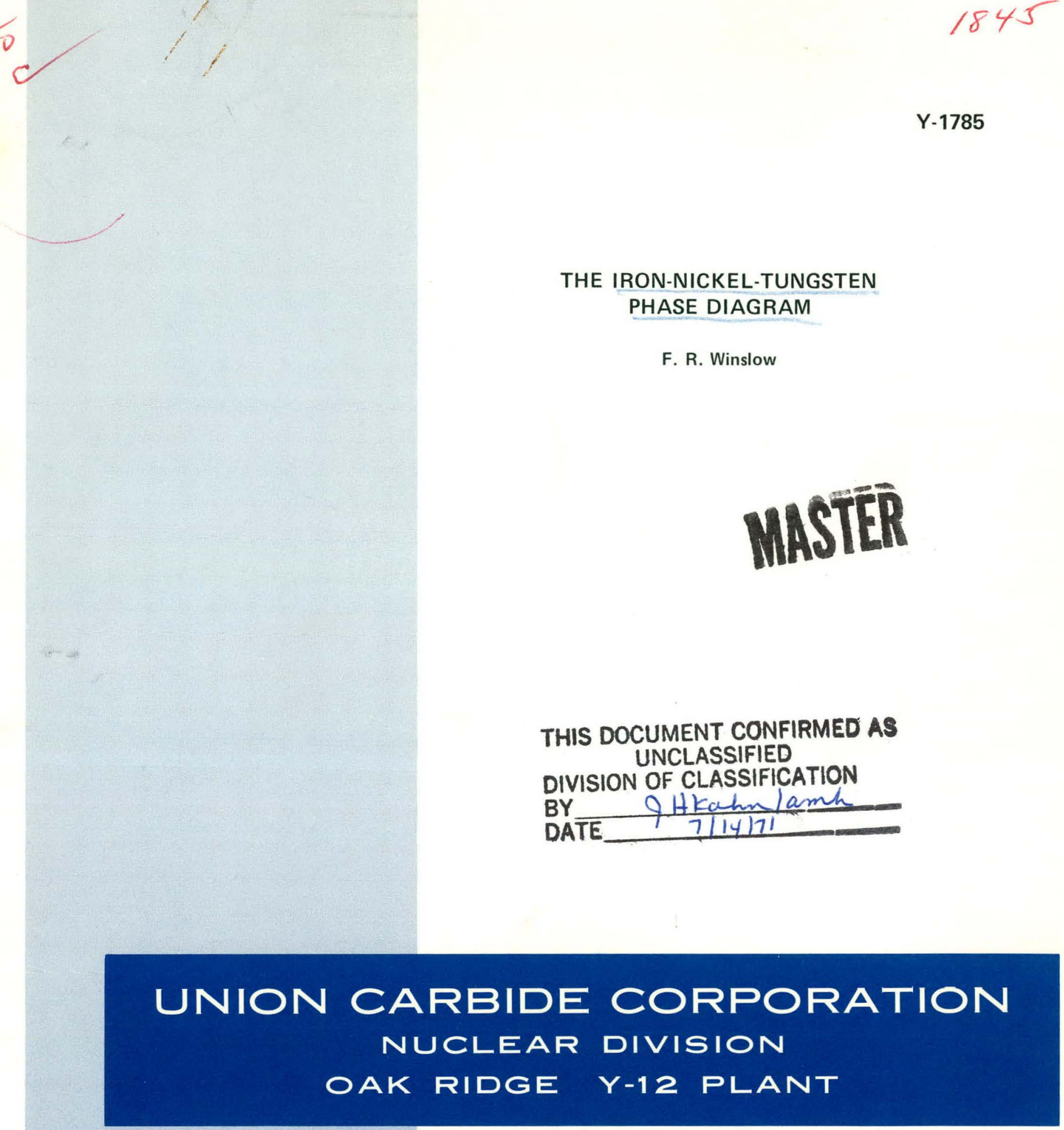

operated for the ATOMIC ENERGY COMMISSION under U. S. GOVERNMENT Contract W-7405 eng 26 


\section{DISCLAIMER}

This report was prepared as an account of work sponsored by an agency of the United States Government. Neither the United States Government nor any agency Thereof, nor any of their employees, makes any warranty, express or implied, or assumes any legal liability or responsibility for the accuracy, completeness, or usefulness of any information, apparatus, product, or process disclosed, or represents that its use would not infringe privately owned rights. Reference herein to any specific commercial product, process, or service by trade name, trademark, manufacturer, or otherwise does not necessarily constitute or imply its endorsement, recommendation, or favoring by the United States Government or any agency thereof. The views and opinions of authors expressed herein do not necessarily state or reflect those of the United States Government or any agency thereof. 


\section{DISCLAIMER}

Portions of this document may be illegible in electronic image products. Images are produced from the best available original document. 
Printed in the United States of America. Available from National Technical Information Service

U.S. Department of Commerce

5285 Port Royal Road, Springfield, Virginia 22151

Price: Printed Copy \$3.00; Microfiche $\$ 0.95$

This report was prepared as an account of work sponsored by the United States Government. Neither the United States nor the United States Atomic Energy Commission, nor any of their employees, nor any of their contractors, subcontractors, or their employees, makes any warranty, express or implied, or assumes any legal liability or responsibility for the accuracy, completeness or usefulness of any information, apparatus, product or process disclosed, or represents that its use would not infringe privately owned rights. 
UC-25

\title{
THE IRON-NICKEL-TUNGSTEN PHASE DIAGRAM
}

\author{
F. R. Winslow
}

\section{Oak Ridge Y-12 Plant}

P.O. Box Y, Oak Ridge, Tennessee 37830

operated for the U.S. ATOMIC ENERGY COMMISSION

bY UNION CARBIDE CORPORATION-NUCLEAR DIVISION

under Contract W-7405-eng-26

Date Issued - June 15, 1971

This rennrt was prepared as an account of work sponsored by the United States Lovermulent. Pfuither the United States nor the United States Atomic Energy Commission, nor any of their employees, nor any of their contractors, subcontractors. or their employees, makes any warranty, express or implied, or assumes any legal liability or responsibility for the accuracy, comn pleteness or usefulness of any information, apparatus; product or process disclosed, or represents that its use would not infringe privately owned rights. 
Document

$Y-1785$

TID -4500

\section{DISTRIBUTION}

Atomic Energy Commission

Keller, C. A.

Zachry, D. S., Jr

Dow - Rocky Flats

Seed, J.R.

Lawrence Radiation Laboratory

Roberts, L. W.

Los Alamos Scientific Laboratory

Taub, J. M./Dougherty, J. E.

Wechsler, J. J.

Oak Ridge Gaseous Diffusion Plant

Jordan, R. G.

Wilcox, W. J., .Jr

Oak Ridge $Y-12$ Plant

Alvey, H. E.

Ammons, A. M.

Bernander, N.K.

Burditt, R. B.

Burkhart, L. E .

Cadden, J. L.

Dean, C. W.

Denny, A. (4)

Dodson, W. H.

Ellingson, R. D.

Evans, G.W.

Gritzner, V. B.

Haeusler, K. R.

Hemperly, V.C.
Hemphill, L. F.

Huber, R. A./Northcutt, W. G., Jr

Hulsey, W. J.

Jackson, V.C.

Johnson, J.R., Jr

Kahl, K. G.

Keith, Alvin

Kite, H. T.

MoLendon, J. D.

Mitchel, G.W.

Myhre, T. C.

Neeley, A. C.

Smith, H. F., Jr

Smith, R. D.

Snyder, W. B., Jr

Stoner, H. H.

Tilson, F. V.

Weathersby, W. E.

Wesley, R. L.

Winslow, F. R. (10)

Yaggi, W. J.

$Y-12$ Central Files (5)

$Y-12$ Central Files (master copy)

$Y-12$ Central Files (route)

$Y-12$ Central Files $(Y-12 R C)$

Paducah Gaseous Diffusion Plant

Winkel, R. A.

Sandia - Albuquerque

Davis, M. J.

Sandia - Livermore

Adolphson, D. R.

In addition, this report is distributed in accordance with the category UC -25 , Metals, Ceramics, and Materials, as given in the "USAEC Standard Distribution Lists for Unclassified Scientific and Technical Reports", TID-4500. 


\section{ABSTRACT}

In support of a study of the properties of liquid-phase-sintered iron-nickel-tungsten alloys, the most probable phase diagram was drawn. The space diagram is shown as a series of isothermal sections between 1,650 and $800^{\circ} \mathrm{C}$ and a liquidus and solidus projection. 


\section{CONTENTS}

SUMMARY ........................ 5

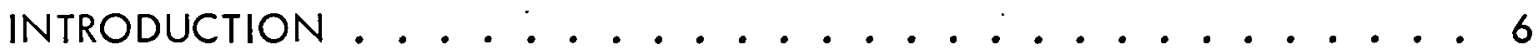

THE IRON-NICKEL-TUNGSTEN SYSTEM. . . . . . . . . . . 7

The Diagram . . . . . . . . . . . . . . . . 7

Discussiuri ..................... 20

REFERENCES ........................ 21 
The iron-nickel-tungsten phase diagram has been reconstructed in the light of present data. Several speculations from these data, incomplete as they are, are in line with current technology in the production of high iron-nickel-tungsten alloys. 


\section{INTRODUCTION}

The iron-nickel-tungsten phase diagram was the subject of a classic paper by Winkler and Vogel. (1) Their diagram has several serious drawbacks in the light of present knowledge. First; no use was made of isothermal sections to represent the space diagram; and, second, more recent information on the binaries forces a revision of the ternary. In the nickel-tungsten binary, a phase, $\mathrm{WNi}_{4}$ decomposing peritectoidally at $970^{\circ} \mathrm{C}$, is fairly well established. The diagram reported by Hansen(2) has been used here. The phase reported by Winkler and Vogel, WNi 6 , is considered to be extremely doubtful, but the possibility of its occurrence is mentioned by Elliot(3) and Shunk. (4)

In the iron-tungsten binary, (2) there are two intermediate phases, $W \mathrm{Fe}_{2}$ and $\mathrm{W}_{2} \mathrm{Fe}_{3}$. Winkler and Vogel show only $\mathrm{W}_{2} \mathrm{Fe}_{3}$. In the iron-nickel binary, no new phases except an ordered phase, FelNi3, have been reported. Further work on the delta ferrite portion of the diagram, however, has significantly changed the phase boundaries. This study does not consider the diagram below $800^{\circ} \mathrm{C}$, thus avoiding the appearance of $\mathrm{FeNi}_{3}$, the boundaries of which are not well known.

Recently, Agababova and Chaporova(5) have studied the gamma-tungsten phase boundary between nickel-to-iron ratios of $30 / 70$ and $80 / 20$ in a temperature range of 800 to $1,350^{\circ} \mathrm{C}$. Their data, in general, agree fairly well with that of Winkler and Vogel. At lower temperatures and lower nickel-to-iron ratios, the gamma phase consistently has a lower tungsten content, while at an 80-to-20 ratio, the tungsten content is consistently high. At the 30-to-70 ratio, they reported weak unidentified lines which are presumably the $\mathrm{WFe}_{2}$ and $\mathrm{W}_{2} \mathrm{Fe}_{3}$ phases. The $\mathrm{WNi}_{4}$ phase does not show up in their samples.

A number of workers have reported on the properties of liquid-phase-sintered, hightungsten-content alloys. These materials can have considerable ductility at room temperature. They have possible potential as shielding in the nuclear industry, at least in locations where formability is necessary. However, the ir properties, especially ductility, appear to vary greatly with the nickel-to-iron ratio in the matrix phase.

The purpose of this study at the Oak Ridge $Y-12$ Plant (a) was to derive a probable ternary diagram, correcting the work of Winkler and Vogel in the light of more recent knowledge. This study might serve as a starting point to explain some of the contradictory data in the literature. A concurrent review of the literature on the preparation and properties of iron-nickel-tungsten alloys is in preparation.

(a) Operated for the US Atomic Energy Commission by the Union Carbide Corporation's Nuclear Division. 


\section{THE IRON-NICKEL-TUNGSTEN SYSTEM}

\section{THE DIAGRAM}

A liquidus and solidus projection of the system, very much as drawn by Winkler, is presented in Figure 1. The phases present throughout the diagram are listed in Table 1.

Table 1

PHASES PRESENT IN THE IRON-NICKEL-TUNGSTEN PHASE DIAGRAM

\begin{tabular}{llc}
\hline \multicolumn{1}{c}{ Phase } & \multicolumn{1}{c}{ Structure } & $\begin{array}{c}\text { Maximum } \\
\text { Temperature } \\
(0 \mathrm{C})\end{array}$ \\
\hline Liquid & bcc & - \\
Tungsten & Hexagonal (40 atoms/cell) & 3,410 \\
$X_{i}\left(\mathrm{~W}_{2} \mathrm{Fe} 3\right)$ & bcc & 1,640 \\
Alpha $(\mathrm{Fe})$ & fcc & 1,534 \\
Gamma $\left(\mathrm{Fe}_{2}, \mathrm{Ni}\right)$ & Hexagonal $(12$ atoms $/$ cell $)$ & 1,511 \\
Epsilon $\left(\mathrm{WFe}_{2}\right)$ & bct $(10$ atoms/cell) & 1,040 \\
Beta $\left(\mathrm{WNi}_{4}\right)$ & & $\sim 970$ \\
\hline
\end{tabular}

At $1,465^{\circ} \mathrm{C}$, a Class II, four-phase reaction occurs: $\alpha+L \rightleftarrows \gamma+\xi$. At $1,455^{\circ} \mathrm{C}$, another Class II, four-phase equilibrium occurs: $\xi+L \rightleftarrows \gamma+W$. These are indicated in Figure 1 with the compositions and temperatures of Winkler and Vogel. In addition, there is a minimum in the liquidus surface proceeding from the iron-nickel side. This shows as a minimum in the liquidus valley, as indicated by the arrows on the lines.

An additional four phase reaction occurs in the solid state at $1,020 \pm 20^{\circ} \mathrm{C}$. This reaction is a Class III (ternary peritectoid): $\alpha+\xi+\gamma \rightleftarrows \epsilon$. This reaction was not observed by Winkler and Vogel. The four-phase reaction plane is not shown in Figure 1, but will be discussed later.

Figure 2 shows the section at $1,650^{\circ} \mathrm{C}$. It is typical of all sections higher than $1,640^{\circ} \mathrm{C}$, the highest stability temperature for $\mathrm{W}_{2} \mathrm{Fe} 3$. The higher temperature measurements of Winkler and Vogel are probably off calibration by about $70^{\circ} \mathrm{C}$ in that they do not show the existence of this compound above $1,570^{\circ} \mathrm{C}$ in any section. These temperature discrepancies exist only at the highest temperatures, disappearing at $1,450^{\circ} \mathrm{C}$ and below. Figure 3 shows the existence of the $\xi$ phase at $1,560^{\circ} \mathrm{C}$. Points plotted on the liquidus have been extrapolated to pin the liquid end of the $\xi-W-L$ tie triangle. Winkler and Vogel's section between 7.5 percent nickel and tungsten, which should go through the three-phase field, does not, presumably because of the temperature error just mentioned. 


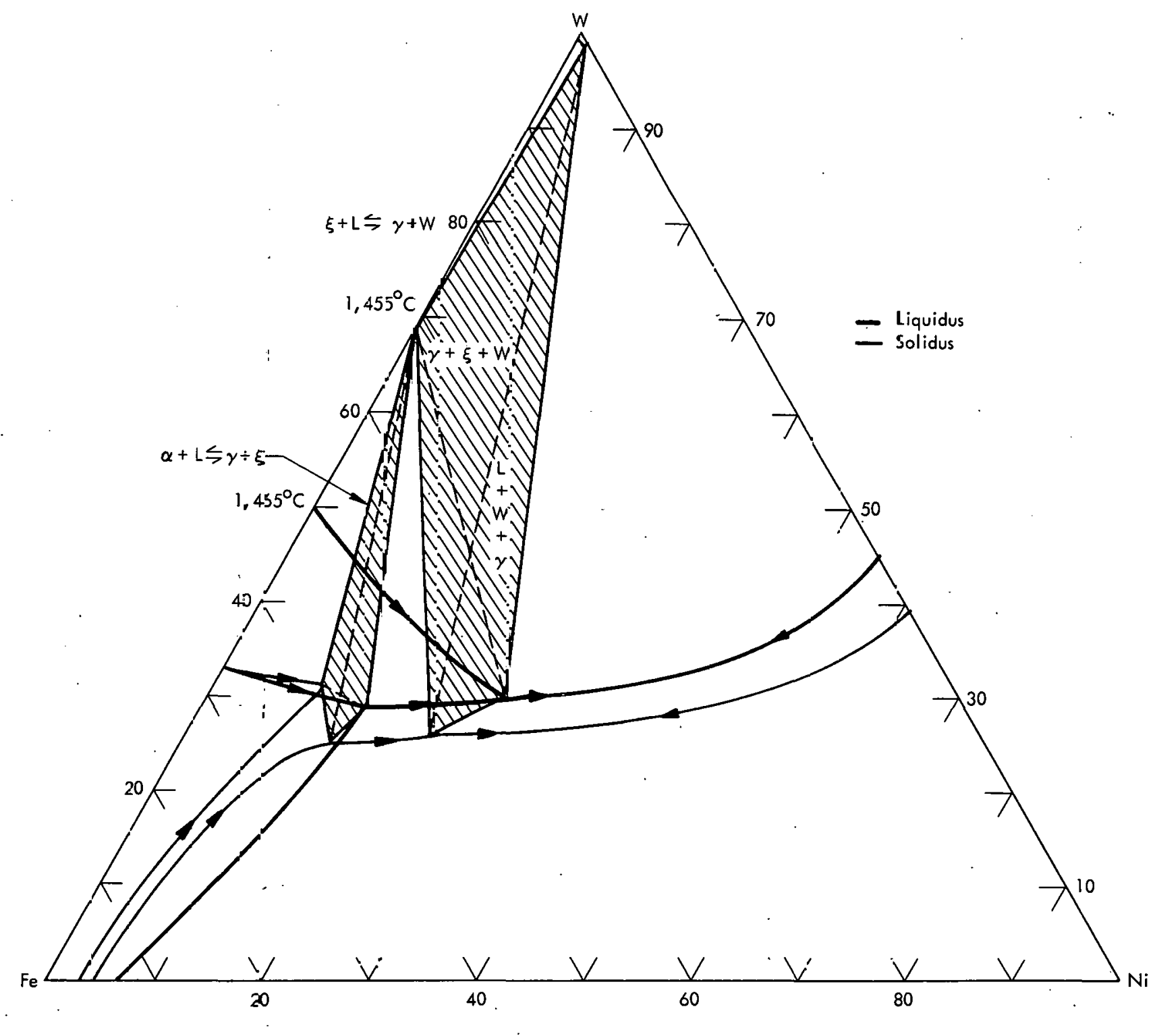

Figur: 1. LIQUIDUS AND SOLIDUS PROJECTION. 


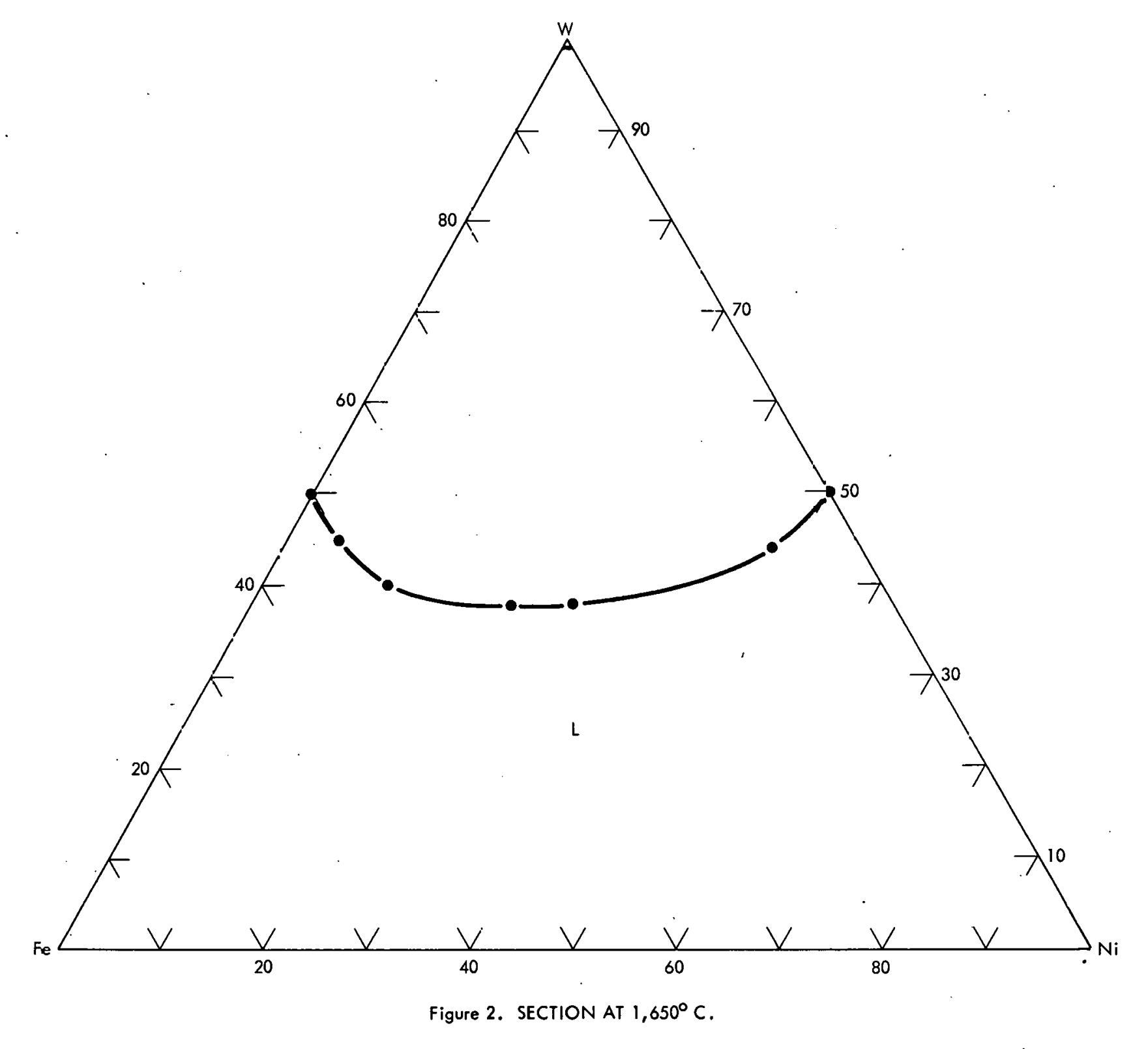




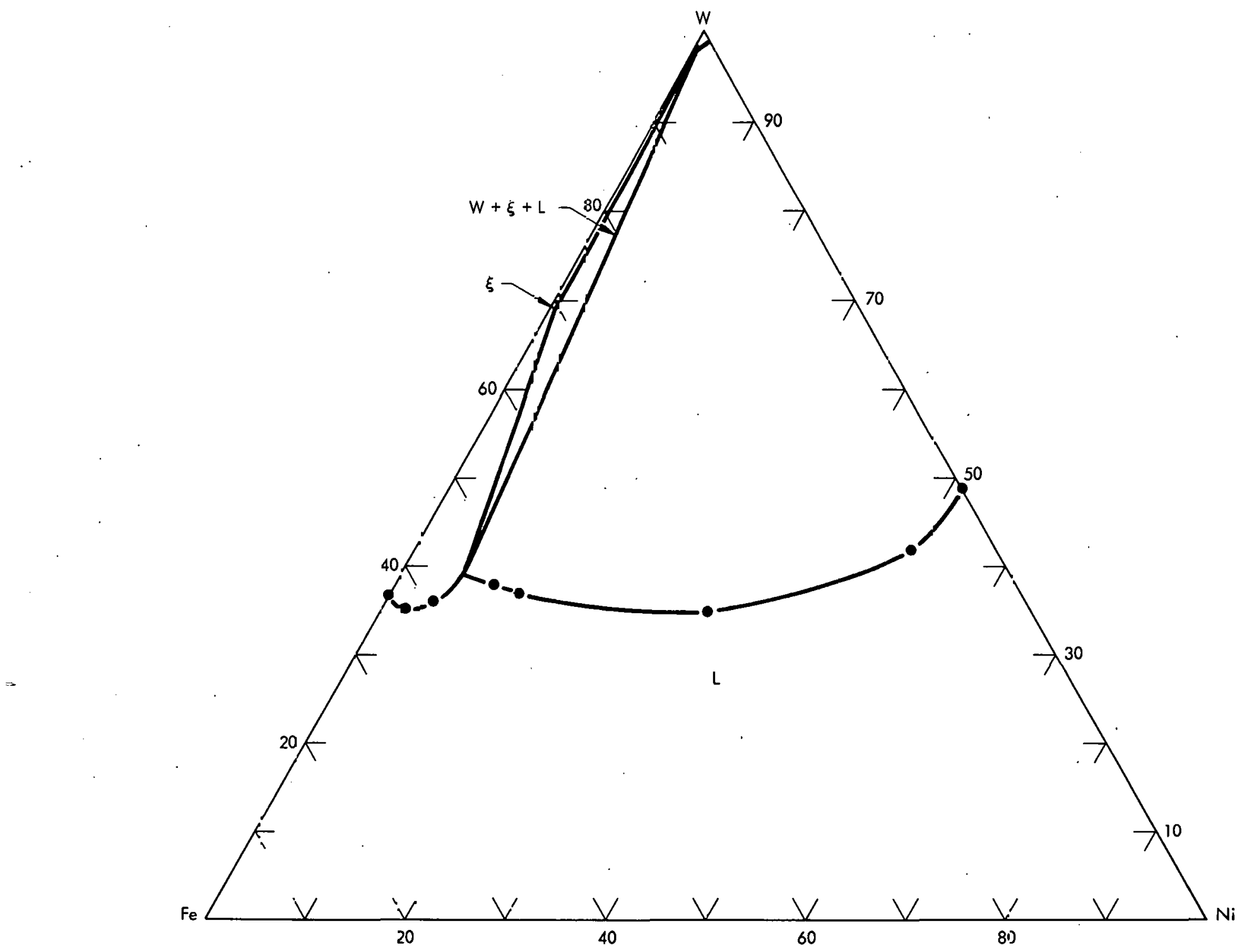

Figure 3. SECTION AT $1,560^{\circ} \mathrm{C}$. 


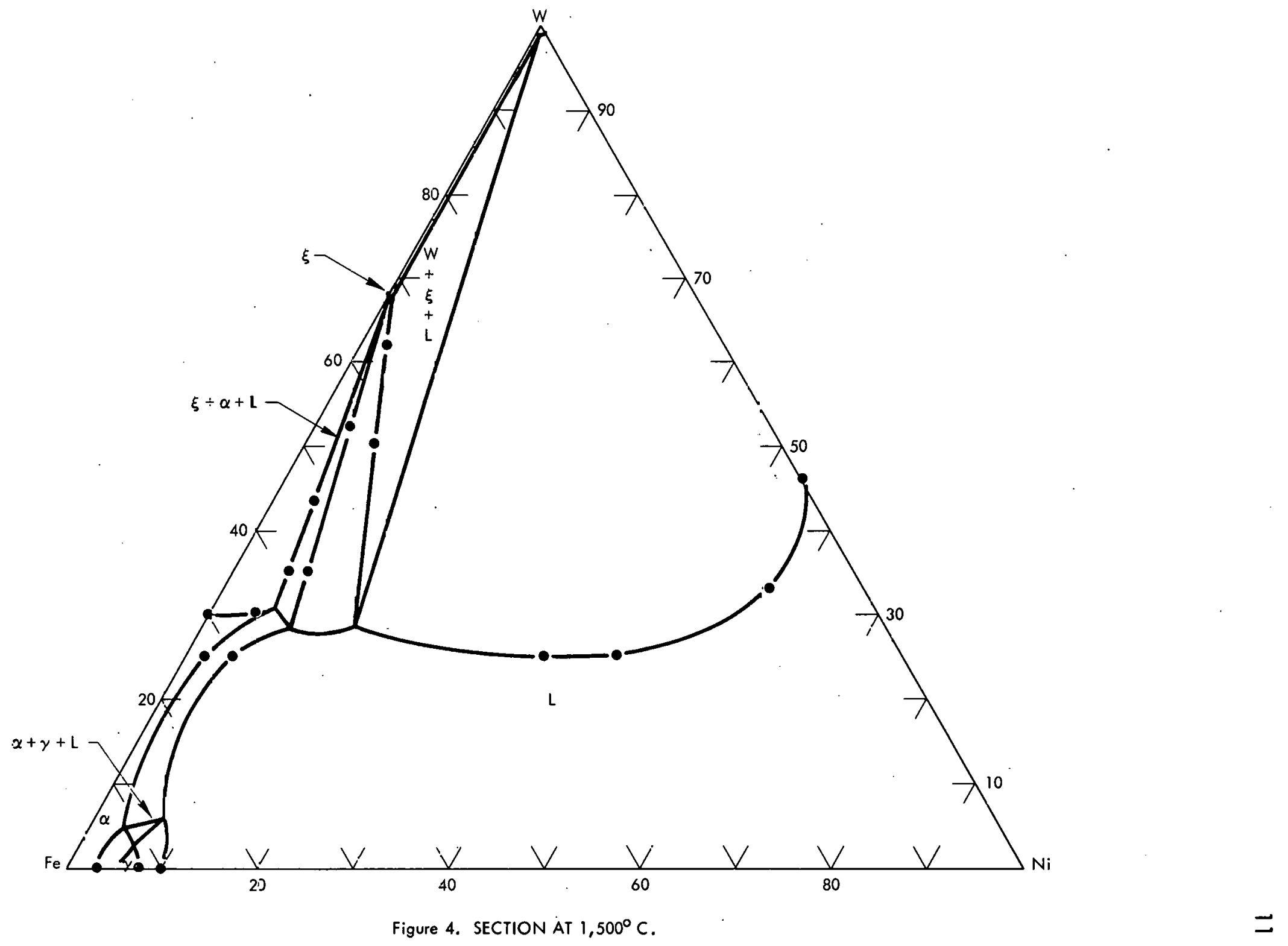




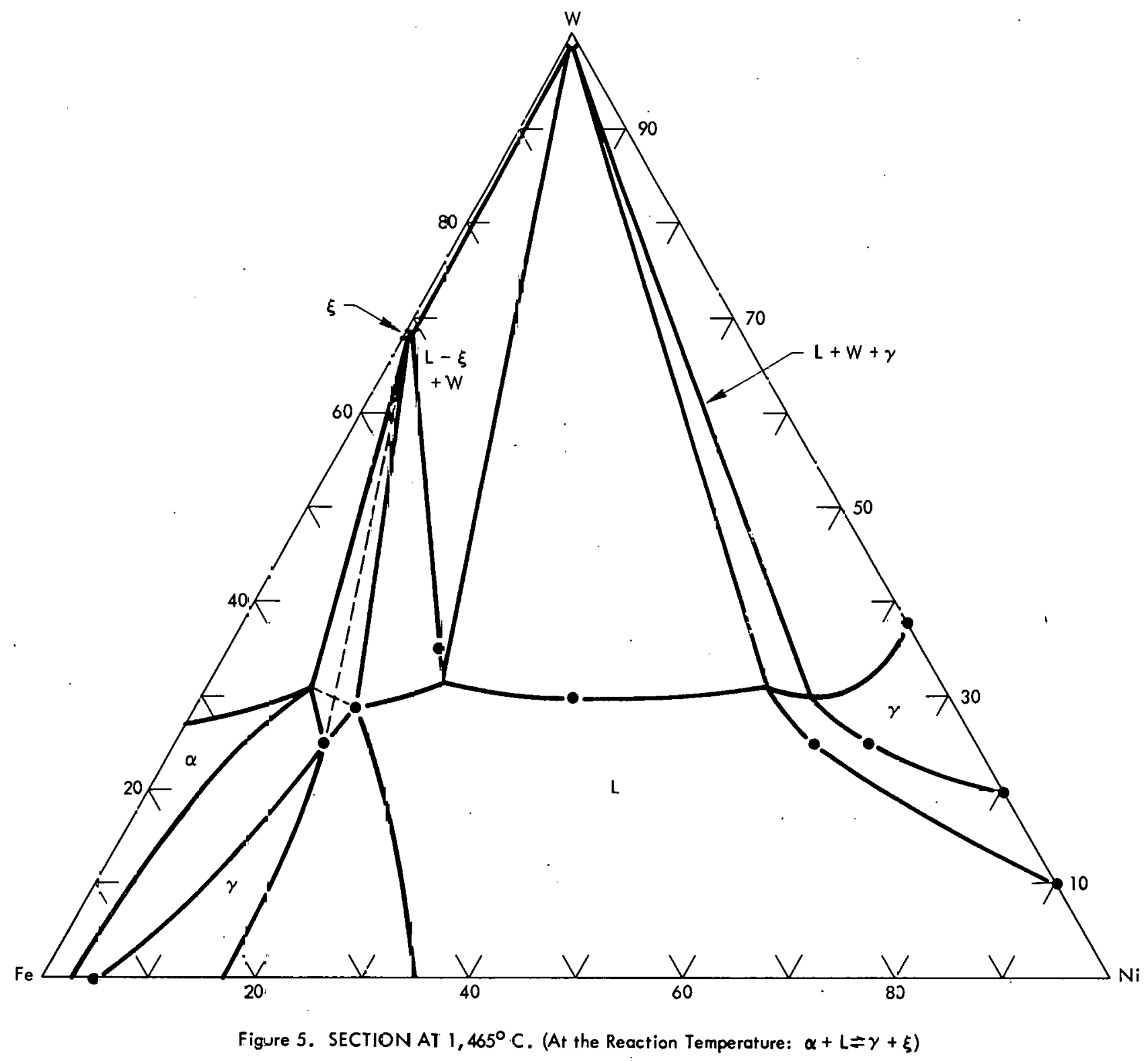

$\vec{N}$ 


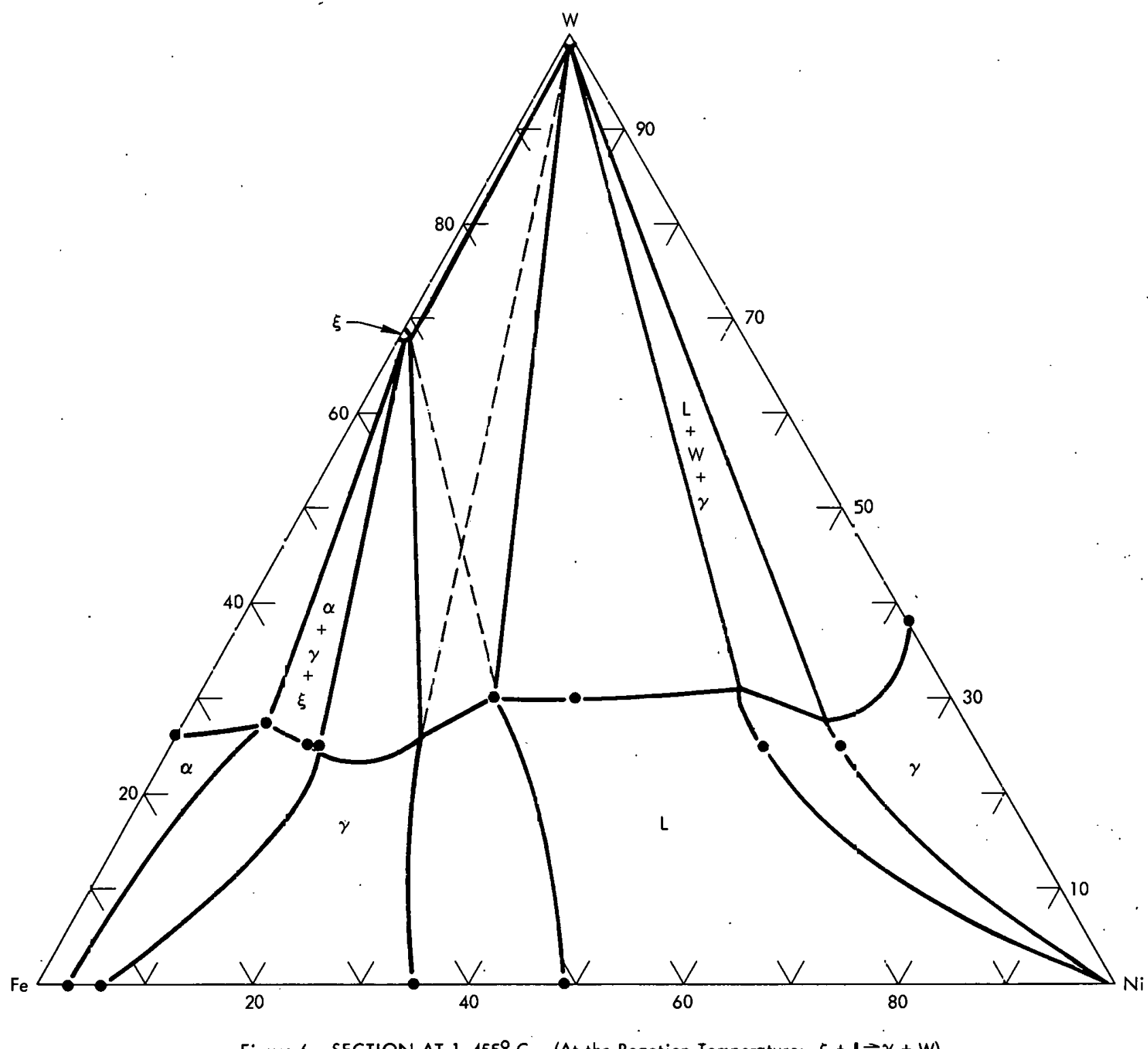

Figure 6. SECTION AT $1,455^{\circ} \mathrm{C}$. (At the Reaction Temperature: $\xi+L \neq \gamma+W$ )

$\vec{\omega}$ 
At $1,500^{\circ} \mathrm{C}$ (Figure 4), $\alpha$ phase has appeared along the iron-tungsten side and ironrich gamma phase along the iron-nickel side, leading to two new tie triangles $(\alpha-\gamma-L$ and $\alpha-\xi-L)$. Points plotted from the vertical sections tie down the positions of the $\alpha-\xi-L$ and $\xi-W-L$ triangles, but the $\alpha-\gamma-L$ triangle is largely schematic. The temperature of the four-phase reaction: $\alpha+L \rightleftarrows \gamma+\xi\left(1,465^{\circ} \mathrm{C}\right)$ is shown in Figure 5 . At this temperature, the $\alpha-\gamma-L$ and $\alpha-\xi-L$ tie triangles combine in a Class $\|$ reaction, the three-phase equilibria below being $\alpha-\gamma-\xi$ and $\gamma-\xi-L$, as shown by the dotted lines on the tie trapezium. Because a $\gamma$ phase has become stable on the nickel-tungsten side, a $\gamma-W-L$ tie triangle is now sweeping toward the center of the diagram. Since experimental points are more scattered on this side of the diagram, the position of this tie triangle is not firmly established. Note that both $\gamma$ fields are $\mathrm{fcc}$, although their compositions vary greatly. Ten degrees lower (at $1,455^{\circ} \mathrm{C}$ ), Figure 6 shows the second four-phase equilibrium:

$L+\xi \rightleftarrows \gamma+W$. This tie trapezium splits into $\gamma-\xi-W$ and $\gamma-W-L$ tie triangles which carry on to lower temperatures. Since $1,455^{\circ} \mathrm{C}$ is the melting point of nickel, the $\gamma+L$ field goes to a point at the nickel corner.

As seen in Figure 7 , at $1,450^{\circ} \mathrm{C}$ there are very rapid changes in the extent of the liquid field just below the four-phase isotherm. By $1,400^{\circ} \mathrm{C}$ (Figure 8 ), the liquid phase has disappeared and the two separate $\gamma$ phases have become joined. (b) The $\alpha$ phase is becoming more restricted, but the $\alpha-\gamma-\xi$ tie triangle is growing as the temperature decreases further. Also, the solubility of tungsten in gamma is decreasing at $1,050^{\circ} \mathrm{C}$, as indicated in Figure 9. No new fields appear.

At $1,000^{\circ} \mathrm{C}$ (Figure 10), the $\epsilon$ phase or WFe 2 has become stable in a Class III reaction: $\alpha+\xi+\gamma \rightleftharpoons \epsilon$, leading to three tie triangles: $\alpha-\gamma-\epsilon, W--\xi$, and $\gamma \in-W$. There is, however, very little change in shape of the phase fields above and below the equilibrium $\left(\sim 1,020 \pm 20^{\circ} \mathrm{C}\right)$. Winkler and Vogel were not aware of the existence of this transformation.

Although Winkler and Vogel were also unaware of the existence of $\beta$ phase, $\mathrm{WNi}_{4}$, at a temperature of about $970^{\circ} \mathrm{C}$, their vertical sections clearly show its existtence if they are plotted as isotherms. The $\gamma+W / \gamma$ boundary no longer sweeps to the nickel-tungsten side as a smooth curve. For example, Figure 11 (at $800^{\circ} \mathrm{C}$ ) shows the characteristic kink in this line, indicating the end of a tie triangle. Unfortunately, there are not enough data to show how large is the composition range where the $\beta$ phase is to be expected. The $\gamma-\beta-W$ tie triangle is drawn (dotted) at approximately its maximum possible extent into the ternary. The existence of a beta precipitate probably has some influence on the ductility of these alloys.

(b) On this and succeeding figures the data points of Agababova and Chaparova(5) for the gamma-tungsten solvus are plotted as crosses. However, the lines are drawn through the points of Winkler and Vogel. (1) 


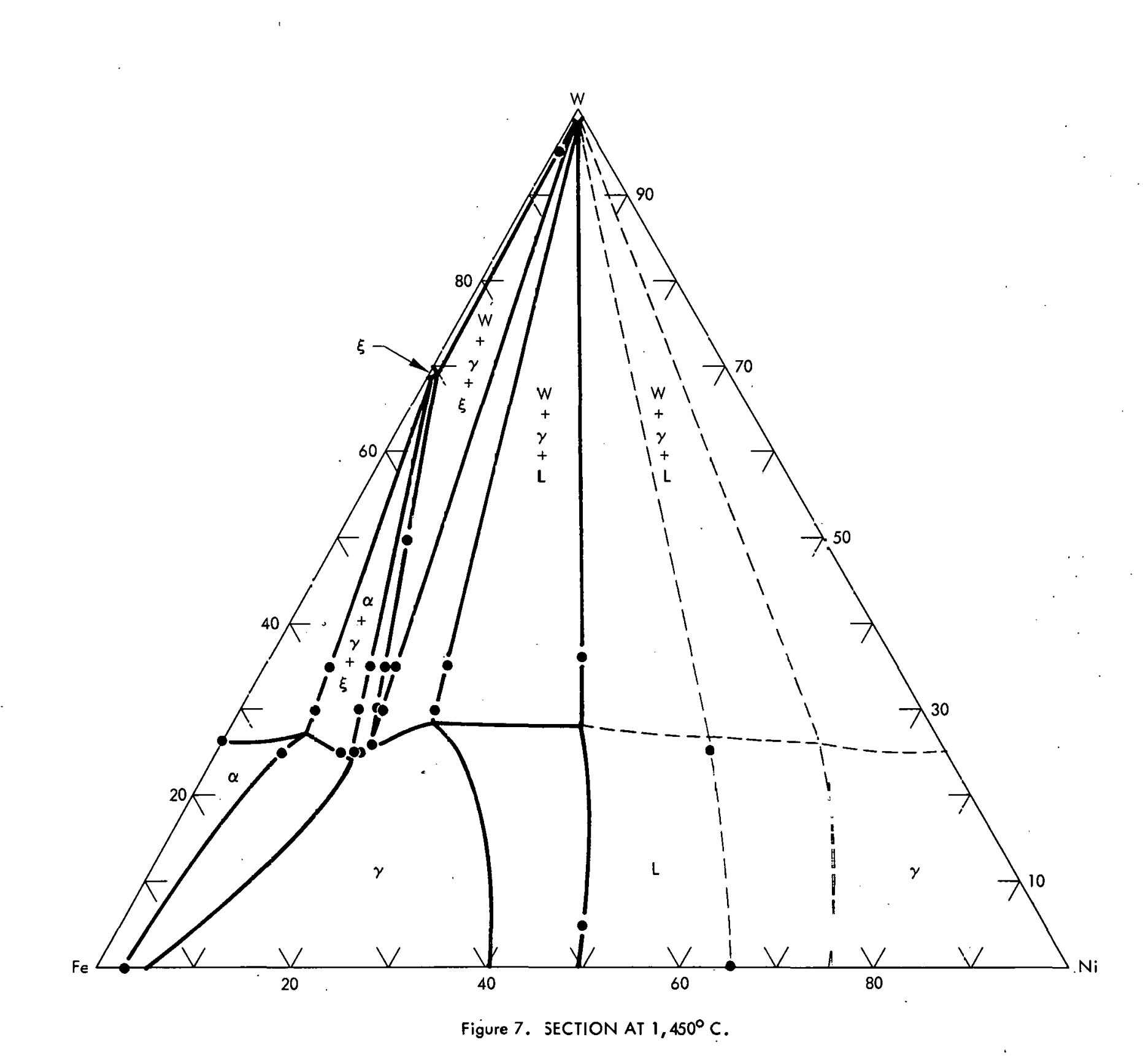




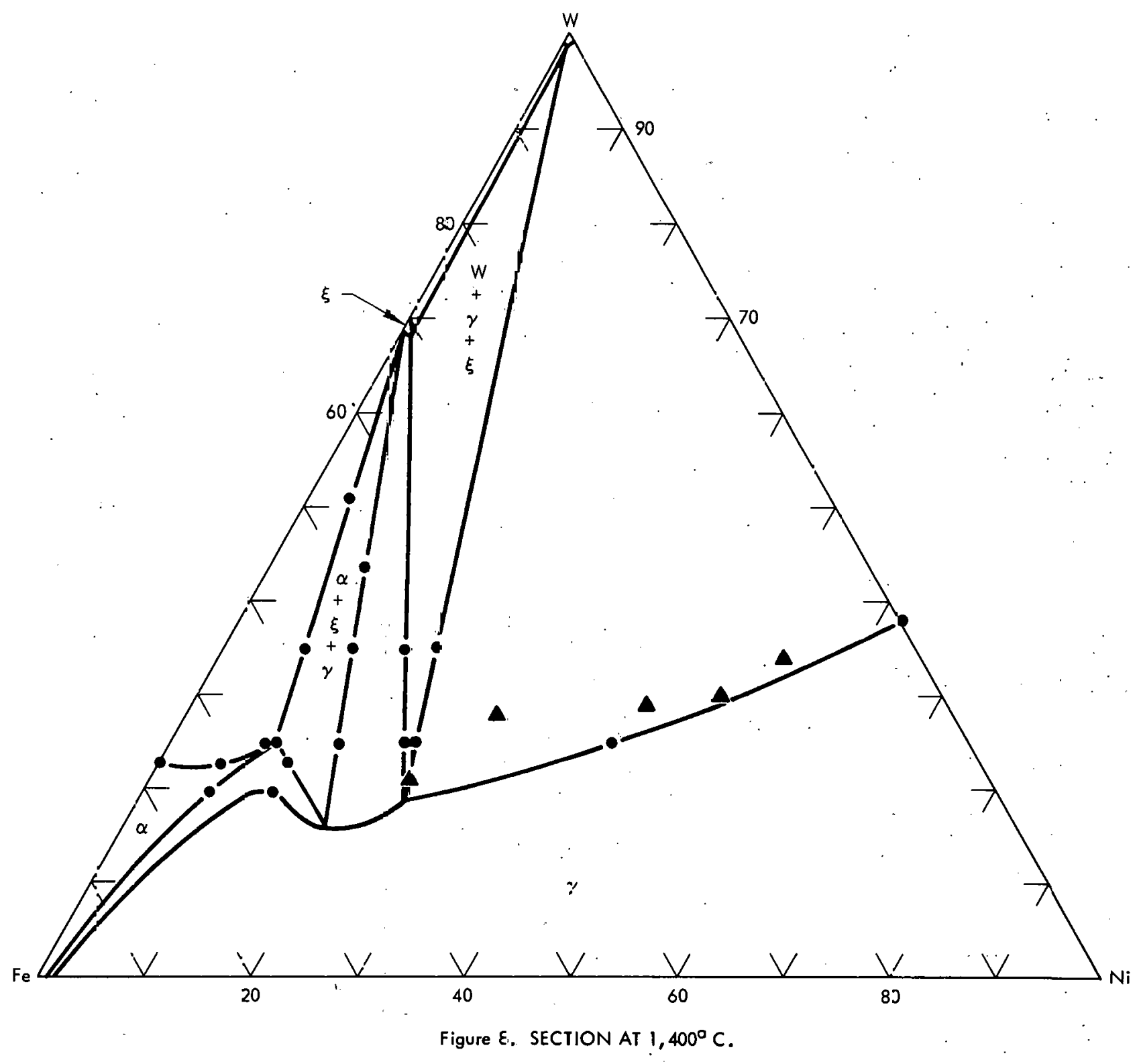

$\bar{\sigma}$ 


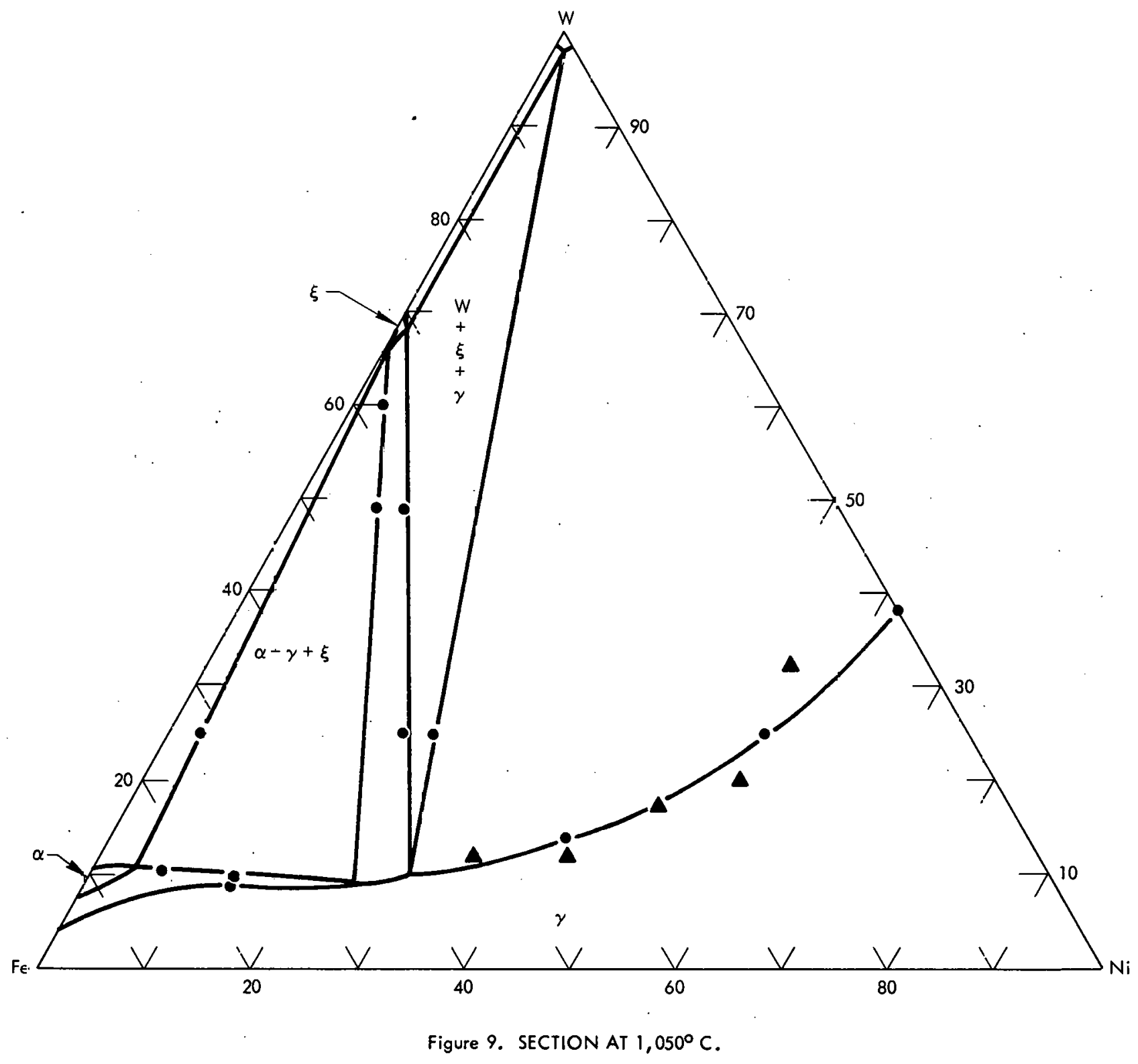

$\bar{v}$ 


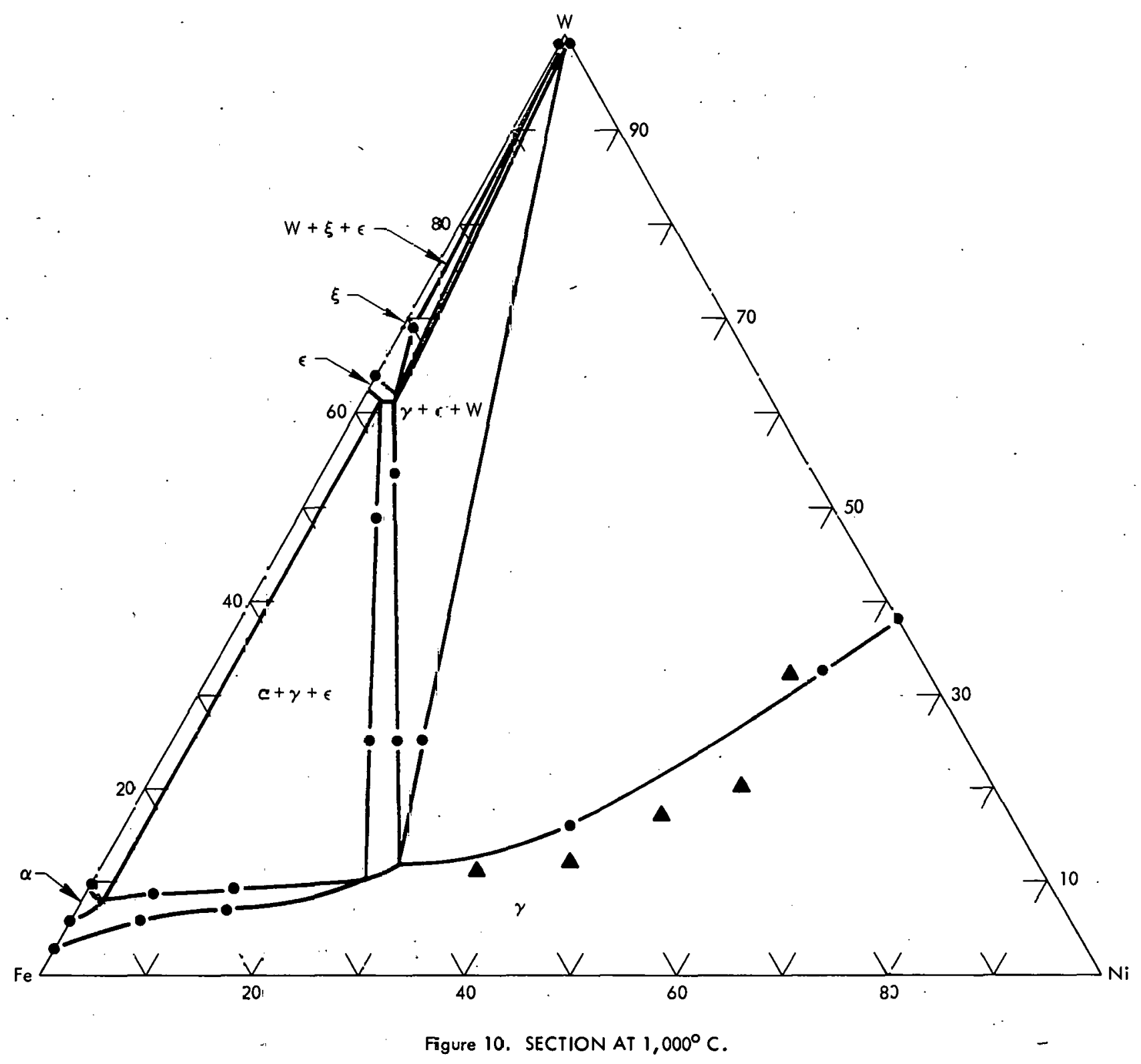

$\vec{\infty}$ 


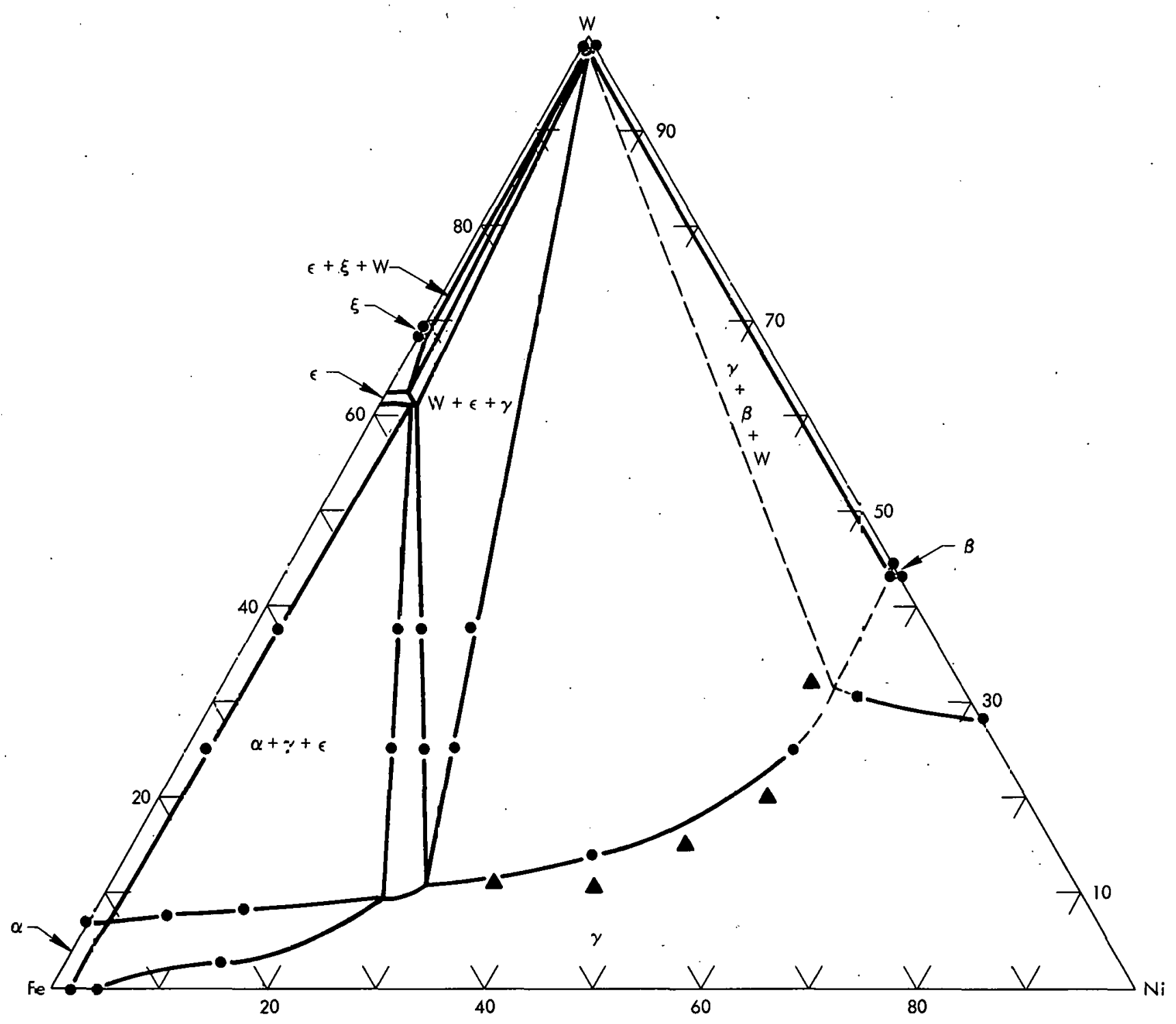

Figure 11. SECTION AT $800^{\circ} \mathrm{C}$.

$\overrightarrow{0}$ 


\section{DISCUSSION}

The configuration of this diagram, as shown in the figures, can lead to speculation as to the properties and sintering behavior of high tungsten alloys. First, the exact sintering temperature should probably be chosen so that gamma phase is not pressent in the alloy. This is easy at $1,500^{\circ} \mathrm{C}$; but, at $1,450^{\circ} \mathrm{C}$, only a limited range of nickel-to-iron ratios is possible. It appears that at $1,465^{\circ} \mathrm{C}$, ratios of $1 / 2$ to $4 / 1$ are possible. If the sintering temperature is to be limited to prevent grain growth of the tungsten particles, the only suitable nickel-to-iron ratios lie between $1 / 1$ and $6.5 / 4.5$.

Second, it appears that a homogenization anneal at any temperature between 1,000 and $1,400^{\circ} \mathrm{C}$ would bring the alloy to the desired two-phase $(\gamma+W)$ structure. After such an anneal, the tungsten content in the matrix $\gamma$ phase would increase with the nickel content, presumably strengthening the matrix by solid solution hardening.

Third, it appears that nickel-to-iron ratios greater than $5 / 1$ would lead to precipitation of $\beta$ phase, WNi $\mathrm{W}_{4}$. Perhaps this would only occur during slow cooling, but no study of the kinetics has been done. Possibly this precipitation has led to the general observation that the ductility of the material increases up to nickel-to-iron ratios of $4 / 1$ and decreases sharply above that. 


\section{REFERENCES}

(1) Winkler, K. and Vogel, R.; Arch f.d. Eisenhüttenwesen, 6, p 165 (1932).

(2) Hansen, M. and Anderko, K.; Constitution of Binary Alloys; McGraw-Hill Book Company, New York (1958).

(3) Elliott, R. P.; Constitution of Binary Alloys, First Supplement; McGraw-Hill Book Company, New York (1965).

(4) Shunk, F. A.; Constitution of Binary Alloys, Second Supplement; Mc Graw-Hill Book Company, New York (1969).

(5) Agababova, V. M. and Chapuruva, I. N .; Purosh Mer Akad Nauk Ukr SSK, p 67; July 1969. English translation in Soviet Powder Metallurgy and Metal Ceramics, p 571; July 1969. 